\title{
An Analysis of Emerging China's Economy and its Influence on World Economy
}

\author{
Zhijun Sheng (Corresponding author) \\ School of Economics and Management, Changchun University of Science and Technology \\ Changchun 130022, China \\ Tel: +86-135-0445-7191Ｅmail: shengzhijun412@126.com \\ Jing Ma \\ School of Economics and Management, Changchun University of Science and Technology \\ Changchun 130022, China \\ Email: majingdoll@hotmail.com
}

Received: July 22, $2011 \quad$ Accepted: August 21, $2011 \quad$ doi:10.5430/rwe.v2n2p21

\begin{abstract}
Since entering 21st century, the Chinese economy has obtained unprecedented development opportunity, growing rapidly. We emphatically analyze the remarkable performance and the immense changes of the Chinese economy in economic output, foreign trade, foreign investment and enterprise strength, etc. Finally, we point out the reality and potential influence and contribution of emerging China on world economy.
\end{abstract}

Keywords: China’s Economy, Emerging Market, World Economy

At the end of 2010, China's Social Science Institute issued “World economy Yellow Paper” and "International Situation Yellow Paper”, which pointed out China has become the second biggest economy in the world, and has been in the leading position on many aspect. For instance, China ranks second on multinational merger and acquisition and surpasses UK, France and Germany to become the International Monetary Fund's third major stockholder. All the above show since 21st century, China's economy has enjoyed fast development, and emerging China is more and more influencing world economy tremendously.

\section{Performance of Emerging China's Economy}

China's reform and open policy for over 30 years contribute to rapid growing of China's economy. According to the analytical data from an American media monitor organization, “China's growing to be a super economy” is the most attractive news story in the past 10 years in the world, which is paid more attention to than the Iraq War and "911 terror attacks". (2009)The performance of China's economy is mainly showed in the following several aspects.

\subsection{Rapid and Continuous GDP Growing Brings Higher Ranking Position on Gross Output}

In the past more than 30 years, China's economy has grown by $9.7 \%$ annually, ranking first in gross outputs for the first time. According to the data from World Bank, China's GDP surpassed that of Britain in 2006, becoming the fourth biggest economy in the world and accounting for $20 \%$ of global economy. In 2010, because of the difference on economic growth rate for many years, China’s economic output surpassed that of Japan, becoming the global second biggest economy. (2011)Moreover, according to the prediction of multi-country's economists and Goldman Sachs, in the coming 20 years, China annual economic growth rate will maintain about 7\%. By around 2030, China’s economic output will surpass the US, leaping to the world leader.

\subsection{Rapid Growth on Foreign Trade with Largest Export}

Since the reform and opening to the outside world, the Chinese foreign cargo volume of trade has increased suddenly from 20,640 million US dollars in 1978 to 2,561,630 million US dollars in 2008.Although in 2009, because of the loan crises influence it dropped to 2,207,270 million US dollars, in 2010 China's foreign trade created a historical new high record. On March 5, 2011 Premier Wen Jiabao pointed out in the government work report that in 2010 the total amount of Chinese foreign trade achieved 2,970 billion US dollar, with annual growth of 17.4\%, becoming one of the most important factors of rapid economic growth of China. Moreover, in 2009, China surpassed Germany to become the 
world largest export country. Furthermore, according to Li Gang, a researcher of the research institute of international trade and economic cooperation that on quantitative index, China's gross trade volume, including cargo trade and service trade, will amount to about 5,300 billion US dollars by 2020, with about 4,300 billion US dollars on cargo trade and approximate 1,000 billion US dollars on service trade.(Xiao, 2010) By that time, China's cargo trade export amount will amount to about 2,400 billion US dollars, ranking the first in the world; the import amount will amount to about 1,900 billion US dollars, ranking the second in the world.

\subsection{Foreign Exchange Reserve Ranks 1st in the World, and Financial Industry Develops Rapidly and Steadily}

According to the statistical data from the People's Bank of China, in October, 2006, China foreign exchange reserve reached to 1,000 billion US dollars, and amounted to 1,066 billion US dollars at the end of 2006, as 666 times much as that in 1978, ranking the first in the world. According to the statistical data from the People's Bank of China on January 11, 2011, by the end of 2010, China foreign exchange reserve had been 2,847 billion US dollars, growing by $18.7 \%$ compared to the same period. (An, 2011)The large amount of foreign exchange reserve enables China to have the abundant international payments ability, and enhanced China to resist each kind of financial risk. Moreover, since the reform and open policy, especially after joining WTO, the Chinese financial industry has successfully broken the unfavorable situation of foreign and domestic troubles, opening to the outside world with steady steps. One hand, more foreign financial corporations entered China increasingly; On the other hand, Chinese financial corporations went overseas continuously and rapidly, which indicated that China's financial industry was already more open and vigorous, becoming an important new force in the world finance pattern.

\subsection{World Leader and 1st among Developing Countries on Capital Input and the Foreign Investment}

In the capital input aspect, since 1993 China has already maintained $1^{\text {st }}$ in the developing world for 18 years continuously, standing the leading position in the world. In the foreign investment aspect, since 2002, China has increased continuously for 9 year, with higher ranks in the world unceasingly. According to "2009 China Foreign Direct investment Statistical bulletin" issued by the department of commercial affairs, the State Statistical Bureau, National Foreign Exchange Bureau, in 2009 the Chinese net foreign direct investment amounted to 56,530 million US dollars, ranking the fifth globally. Moreover, in recent years, the Chinese Enterprises' multinational merger and acquisition speed up obviously and expanded unceasingly. In 2010, the Chinese merger and acquisition volume reached the second globally. The Chinese Enterprises have changed to buyers from sellers before, mainly focusing on excavation industry with energy as the main purpose.

\subsection{Increasingly Strengthened Enterprises, Ranking First on Manufacturing Industry Globally}

In China, on the process to enterprise-dominant market economy system, the Chinese Enterprises have obtained a fast development. For instance, there were 54 Chinese enterprises among world Top 500 in 2010. Chinese Enterprises have transferred from sellers to buyers on multinational M\&A, from attracting foreign capital to investing abroad. They gradually become to support Chinese economy and even the world economy. China has already entered the era of owning world-class enterprises. The direct performance of increasingly strengthened Chinese enterprise is continuous growth of Chinese manufacturing industry output. According to the latest research of an American consultation institute, China already surpassed the US and become NO. 1 on output of manufacturing industry in the world. In 2010 the manufacturing output of China accounts for $19.8 \%$ in the world, slightly higher than that of the US, $19.4 \%$. Britain Financial Times commented that this means China not only restored to maintain the first of global biggest commodity producer during half of the 19th century, but also has caught up with the US, which has occupied this position for 110 year. (Ji, 2011)

\subsection{Obviously Growing Market Expends}

On market expends, since 1979, the Chinese consumable total volume of retail sales annually has grown by nearly $15 \%$. On March 28, 2011, announced "major economic target and the principal commodities sale situation of nation large-scale retail business in 2010" by China Business Coalition shows that in 2010, China's consumable total volume of retail sales amounts to 15,699,800 million Yuan, growing by $18.3 \%$ compared to 2009 . When deducting the price factor, the actual speed-up achieves $14.8 \%$. The social consumable total volume of retail sales per capita amounts to 11 thousand Yuan, entering officially to ten thousand Yuan times. (Ren, 2010)Particularly after the loan crisis in 2008, in the export disadvantageous situation, China's automobile, electrical appliances, telecommunication product and so on didn't fall but rose instead. One hand this indicated that the Chinese high consumption time has arrived, simultaneously also indicated the expense will strengthen the future China economy unceasingly. 


\section{The influence of Chinese Economy Growth on World Economy}

\subsection{Change the World Industrial Pattern and the Economic Pattern}

As an emerging market with 1,340 million populations, China has presently become the world-class machining center, such as textile, electric appliances, and electron and engineering products. All these Chinese industries maintain dominant positions. China, as a great nation of global manufacturing industry, has changed the world industry chain link enormously, and has the enormous influence on the world economics pattern. China, located at industrial chain terminal, has fully stimulated the Asian countries' economic growth and the employment expansion. At the same time, the market power of consumption due to Chinese economy growing unceasingly, also attracted the national enterprises outside Asia to China to invest, and changed its global industry and the related adequate and systematic service layout unceasingly, which will certainly cause the entire world economics pattern center shifting to Asia.

\subsection{Intensify the World Market Competition}

At the same time, along with the China's opening up policy and the domestic market's expansion, the world high-tech manufacturers also favor China's cost advantage and the market prospect, therefore China has attracted numerous formidable multinational corporations' investment all over the world. These enterprises rely on the superiority of labor power, using the world resources and raw material to produce goods with competitive and send them to the world market, which intensified the market competition in world raw material and products markets. On the other hand, through the development for over 30 years since the reform and open policy, China has become the important participants on global economy, trade, finance and the investment and so on, and large Chinese Enterprises also go out to develop in international market, which also cause the competition to be more intense in the world market undoubtedly.

\subsection{Reduces Harm of the World Economics Crisis, Maintain World Economic Growth}

At the end of $20^{\text {th }}$ Century and beginning of this Century, the capitalism world fell into economic crisis's frequency period once again. While Chinese economy was swift growing, the world or regional economy has had big financial crises twice, namely 1979 southeast financial crisis and 2007 American loan crisis, moreover also receives the European debt crisis's puzzle at present. In these crises, China not only displayed the superiority of socialist market economic system at the resistance of economic crisis, and successfully avoided crisis's big impact, but also helped some countries falling into crisis to go out of the trough. China's breakthroughs of reform and open policy, economic system and developmental strategy undoubtedly have significance to the developing countries in general and even to the world profits. Moreover, because the process of the Chinese economy rising is a peaceful development process, different from the Western countries, it conforms to the general trend which the world pursue economy altogether now. Therefore it certainly has a profounder influence regarding world economic long-term stability development.

\subsection{The Influence on International Finance and Monetary System}

Along with China's rising, the internationalization of RMB is no longer only the fancy theoretically. Some countries and regions, especially China's peripheral neighboring countries, have started to attempt using RMB to carry on trade. Since December of 2008, the Chinese Central Bank have successively signed the agreement of standard currency to exchange with South Korean, Chinese Hong Kong, Malaysia, Belorussia, Indonesia, Argentina, Iceland and Singapore. These currency exchange agreements undoubtedly have advantages to the RMB's expansion, and display the function of RMB on accounting and currency reserve. It also symbolizes that the internationalization of RMB is speeding up. Meanwhile, China and some developing countries have also obtained the enhancement of words power in the IMF. China and some emerging industrial nations already had enough strength to resist each kind of selfish monetary policy by US and Europe, which causes the whole world money economy's power authority no longer completely to be grasped by the minority big national champions, like US and Europe. It will urge the world to establish one fairer, and highly effective international finance and monetary system.

\subsection{Challenge the Dominant Position of Western Developed Countries}

Chinese economy rising will also challenge the Western developed countries in world economics dominant position thoroughly and gradually. Before the Chinese economy's rising, although some emerging industrial nations and areas (for example, the Asian four dragons) competed with and attacked the US, Europe and Japan, they were limited by their comprehensive strength, which were radically unable to compete with those countries. Rising China, strengthened emerging economy, has great strength without doubt. In many aspects, China has surpassed the developed countries unceasingly, which symbolizes that China started to compete with and challenge US, Europe and Japan on economic status, weakening their superiority and influencing their dominant position tremendously.

\subsection{Impel the Transformation and Adjustment of International Economy Mechanism and Order}


China, as a great nation of socialism and one of the eastern ancient nations, has more words power in the international affairs. China is not only the permanent member of United Nations, moreover joined WTO, becoming the IMF's third major stockholder, as well as a member of the five gold brick countries and the G20. All these enable China to have more opportunities and bigger authority to participate in the international economy mechanism and the order reform negotiations, finally will speed up the transformation and the adjustment to the international economy mechanism and the order, which has the positive significant influence.

\section{References}

"The Chinese economy rises” is evaluated for ten years. Global most flash news. Reuter, [Online] Available: http://cn.reuters.com/article/cnInvNews/idCNCHINA-1281520091208.(Dec. $\left.8^{\text {th }}, 2009\right)$

An Bei, Hou Xuejing.(2011)China foreign exchange reserve remaining sum is 2,847,300 million US dollars at the end of 2010. New China net. (Jan. 11 ${ }^{\text {th }}$, 2011)

China surpasses Japan to become the global second biggest economy. Discusses weekly, [Online] Available: http://news.sohu.com/20110305/n279663076.shtml, 2011. (Jan. 20 ${ }^{\text {th }}, 2011$ )

Ji Shuangcheng. (2011)US reported that China becomes the global biggest manufacture country. Global times, Mar. $15^{\text {th }}$, 2011.

Ren Zhenyu. (2010)Social consumable total volume of retail sales per capita enter ten thousand Yuan times. China consumer news, Mar. 30 2010.

Xiao Ming.(2010) Department of commercial affairs research institute: multiplication of Chinese volume of trade in 10 years.21st century business herald, May. 18 ${ }^{\text {th }}, 2010$. 